\title{
Development of EST microsatellite markers for the Tasmanian palaeoendemic conifer Lagaros- trobos franklinii (Hook. f.) Quinn (Podocarpaceae)
}

\author{
James R. Marthick ${ }^{1}$, Matthew J. Larcombe ${ }^{2}$ and James R. P. Worth ${ }^{3 *}$ \\ ${ }^{1}$ Menzies Institute for Medical Research, 17 Liverpool St, Hobart, Australia, 7001.
${ }^{2}$ Department of Botany, University of Otago, PO Box 56, Dunedin, New Zealand, 9054.
${ }^{3}$ Department of Forest Molecular Genetics and Biotechnology, Forestry and Forest Products Research Institute,
Morinosato 1, Ibaraki, Tsukuba, Japan, 305-8687. \\ * Corresponding author: James R.P. Worth, Email: jrpw2326@affrc.go.jp
}

\begin{abstract}
Nuclear Expressed Sequence Tag (EST) microsatellite markers were developed for the Tasmanian palaeoendemic conifer Lagarostrobos franklinii (Hook.-f.) Quinn for genetic studies. RNAseq data was mined for EST microsatellites, and primer pairs were synthesised from 70 contigs with 50 producing amplification products. Of these 50, 10 reliably amplified and displayed polymorphism across 8 samples representing the entire species range. The genetic diversity of these 10 loci was then examined in three wild populations (84 samples). The number of alleles varied from two to thirteen per locus with the average number of alleles per population ranging between 3.0 - 4.7. Observed and expected heterozygosity ranged from $0.34-0.42$ and $0.37-0.44$, respectively. Marker cross-amplification was tested in the New Zealand sister species Manoao colensoi (Hook. f.) Molloy, but no markers amplified reliably, which possibly reflects the age of divergence between these species ( 64 million years). These are the first microsatellite markers developed for the monotypic genus Lagarostrobos. They will be valuable for assessing the species extant genetic diversity, the impact of past climatic perturbations and human disturbance and the role of clonal propagation in recruitment.
\end{abstract}

Keywords: : Lagarostrobos, Podocarpaceae, EST microsatellites, palaeoendemic, next generation sequencing, huon pine, Tasmania.

\section{Introduction}

The Tasmanian conifer Lagarostrobos franklinii (Hook. f.) Quinn (Podocarpaceae), or Huon pine, is a slow growing, mostly dioecious evergreen tree that is restricted to high rainfall parts of western and southern Tasmania (Gibson, et al. 1991). Whilst widespread, its distribution is usually restricted to lowland riparian areas (Peterson 1990) where it is a dominant component of the cool temperate rainforest flora. The species is notable for being one of the longest lived trees in the world with individual stems reaching ages of 2500 - 3000 years (Buckley 1997) and one clonal stand in western Tasmania thought to exceed 10,000 years of age (Anker, et al. 2017).

As with other fire sensitive Tasmanian conifers (Worth, et al. 2017), the current range of $L$. franklinii appears to be strongly influenced by fire. This is supported by the fact that the species is absent from a large proportion of its potential climatic range (Read and Busby 1990) especially in areas away from the fire protection afforded by rivers. Significant, rare stands of non-riverine $L$. franklinii, including some near the subalpine zone (Gibson, Davies and Brown 1991), are found only in long unburnt fire refugia (Gibson 1988).

Lagarostrobos franklinii is a conifer of both considerable conservation significance and concern. The species is phylogenetically isolated being the sole member of a diverged, basal, Podocarpaceae genus (Biffin 2011) and is an important component of the Tasmanian palaeoendemic flora (Jordan, et al. 2016). The closest extant relative is the New Zealand endemic 
Manoao colensoi (Hook. f.) Molloy, a monotypic genus erected from Lagarostrobos (Molloy 1995). European colonisation of Tasmania has had a significant impact on L. franklinii via, logging, hydroelectric inundation, and increased fire frequency and severity (Gibson, Davies and Brown 1991). Lagarostrobos franklinii was harvested extensively from the early 1800 s until the mid- $20^{\text {th }}$ century for its decay resistant timber and consequently, few stands remain untouched (Kerr and McDermott 1999). Overall up to $15 \%$ of its total extent has been lost to hydroelectric schemes (Reid, et al. 1999) while a further $7 \%$ has been impacted by fire (DPIPWE 2011) with very little recovery (Buckley 1997). Furthermore, recent increases in the frequency of fires ignited by dry lightning in western Tasmania (Styger, et al. 2018) pose a severe threat to the species.

Despite intense interest in this iconic species, the only genetic studies to date have used markers with low resolution (i.e. isozymes and chloroplast Sanger sequences) (Clark and Carbone 2008, Shapcott 1997). As a result, detailed population genetic studies have not been possible. This study reports the development of EST microsatellite markers for this ancient and relictual podocarp species, Lagarostrobos franklinii. These markers will be useful for studying existing patterns of genetic diversity and how they relate to climatic fluctuations during the glacial-interglacial cycles and past human impacts and also will also provide insight into the importance of asexual reproduction.

\section{Materials and Methods}

RNA-seq data of $L$. franklinii was obtained from the Plant OneKP Project repository (http://www.onekp.com). This data consisted of 22,888,026 paired end reads of $90 \mathrm{bp}$ in length. De novo assembly was undertaken in CLC Genomics Workbench 8.5.1 (Qiagen, Denmark) and the 52,802 resultant contigs (N50 $=1344$ ) were mined for microsatellite regions. Primers were then developed for each region using default settings in PrimerPro (http://webdocs.cs.ualberta.ca/ yifeng/primerpro/). Microsatellites were targeted if they consisted of over 8 tandem repeats and the microsatellite was located $>25 \mathrm{bp}$ from the beginning or end of the contig. These criteria resulted in 70 microsatellite primer pairs and each primer pair was tested for amplification in four samples. For all loci, the forward primer was synthesized with one of three different M13 sequences (5'-GCCTCCCTCGCGCCA-3', 5'-GCCTTGCCAGCCCGC-3', and $5^{\prime}$-(AGGACCAGGCTACCGTG- $\left.3^{\prime}\right)$, and the reverse was tagged with a PIG-tail (5'-GTTTCTT-3'; (Brownstein 1996). PCR amplification was performed using the QIAGEN Multiplex PCR Kit (Qiagen, Germany) and consisted of a $10 \mu \mathrm{L}$ reaction volume, containing approximately $5 \mathrm{ng}$ of DNA, $5 \mu \mathrm{L}$ of $2 \times$ Multiplex PCR Master Mix, $0.06 \mu \mathrm{M}$ of forward primer, $0.1 \mu \mathrm{M}$ of reverse primer, and $0.08 \mu \mathrm{M}$ of fluorescently labeled M13 primer. The PCR profile consisted of an initial denaturation at $95^{\circ} \mathrm{C}$ for 3 minutes; followed by 35 cycles of $95^{\circ} \mathrm{C}$ for 30 seconds, $60^{\circ} \mathrm{C}$ for 3 minutes, $68^{\circ} \mathrm{C}$ for 1 minute; with a final 20-minute extension at $68{ }^{\circ} \mathrm{C}$. The amplification products were separated by capillary electrophoresis on an ABI 3130 Genetic Analyzer (Life Technologies, Waltham, Massachusetts, USA) with the GeneScan 600 LIZ Size Standard (Life Technologies). Genotype calling was completed with GeneMarker software (SoftGenetics, State College, Pennsylvania, USA). Genetic analyses were undertaken in GenAlEx 6.5 (Peakall and Smouse 2006) and GENEPOP 4.2 (Raymond 1995).

A total of 50 primer pairs successfully amplified and were subsequently tested for scoring reliability and presence of polymorphism in eight samples representing the entire species range (data not shown). Ten of these loci were reliably scorable and displayed polymorphism. These loci were subsequently screened in 84 samples from three different populations encompassing the geographic range of $L$. franklinii: Corinna, on the Pieman River in Western Tasmania, the Denison River from the Franklin-Gordon Wild Rivers National Park and Lake Judd from the Southwest National Park (see Appendix 1 for further details). Additionally, 24 individuals of the sister species Manoao colensoi were collected to examine marker transferability. These were from the Okuru River on the South Island of New Zealand $(n=22)$ and the Dunedin Botanic Gardens $(n=2)$ (Table 1).

Table 1

Details of the Lagarostrobos franklinii and Manoao colensoi samples used for assessing the variability of 10 ESTs microsatellites. Accession numbers of pre-existing herbarium specimen's representative of each population sampled are provided.

\begin{tabular}{|c|c|c|c|c|}
\hline Species & Location & $\mathrm{n}$ & GPS coordinates & $\begin{array}{l}\text { Accession } \\
\text { number }\end{array}$ \\
\hline L. franklinii & Corinna & 27 & $\begin{array}{l}41^{\circ} 39^{\prime} 12.97^{\prime \prime} \mathrm{S} \\
145^{\circ} 5^{\prime} 25.81^{\prime \prime} \mathrm{E}\end{array}$ & HO586492 \\
\hline L. franklinii & Denison River & 30 & $\begin{array}{l}42^{\circ} 36^{\prime} 40.24^{\prime \prime} \mathrm{S} \\
145^{\circ} 59^{\prime} 29.49^{\prime \prime} \mathrm{E}\end{array}$ & CBG 8901682.1 \\
\hline L. franklinii & Lake Judd & 27 & $\begin{array}{l}42^{\circ} 58^{\prime} 14.88^{\prime \prime} \mathrm{S} \\
146^{\circ} 25^{\prime} 47.38^{\prime \prime} \mathrm{E}\end{array}$ & CBG 8700443.1 \\
\hline M. colensoi & Okuru River & 22 & $\begin{array}{l}43^{\circ} 53^{\prime} 42.28^{\prime \prime} \mathrm{S} \\
168^{\circ} 55^{\prime} 52.96^{\prime \prime} \mathrm{E}\end{array}$ & OTA 71838-71847 \\
\hline M. colensoi & $\begin{array}{l}\text { Dunedin } \\
\text { Botanic Garden }\end{array}$ & 1 & $\begin{array}{l}45^{\circ} 51^{\prime} 39.77^{\prime \prime S}, \\
170^{\circ} 31^{\prime} 33.79^{\prime \prime} \mathrm{E}\end{array}$ & DBG 19930739 (B) \\
\hline M. colensoi & $\begin{array}{l}\text { Dunedin } \\
\text { Botanic Garden }\end{array}$ & 1 & $\begin{array}{l}45^{\circ} 51^{\prime} 39.77^{\prime \prime} \mathrm{S} \\
170^{\circ} 31^{\prime} 33.79^{\prime \prime} \mathrm{E}\end{array}$ & DBG 20130104 (A) \\
\hline
\end{tabular}

Note: $\mathrm{n}=$ number of individuals sampled. Details of each $L$. franklinii specimen are available online at the Australasian Virtual Herbarium (http://avh.chah.org.au). Of the $22 \mathrm{M}$. colensoi samples collected at Okuru River, 10 were submitted and received accession numbers from the OTA. CBG = Australian National Herbarium, Canberra, Australian Capital Territory, Australia; $\mathrm{HO}=$ Tasmanian Herbarium, Hobart, Tasmania, Australia. DBG = Dunedin Botanic Gardens living collection, Dunedin, New Zealand; OTA = The Otago Regional Herbarium, Dunedin, New Zealand. 
Lagarostrobos franklinii is known to propagate clonally (Gibson, Davies and Brown 1991, Pedley 1980) so identifying clonal individuals an important application of the 10 loci. Therefore, the multi locus probability of identity (PID) for the 10 loci, that is, the probability that when two individuals drawn at random from a population will have the same genotype (Waits, et al. 2001), was calculated in Gimlet version 1.3.3 (Valiere 2002). Three PID estimates outlined by Waits et al. (2001) were estimated: biased PID which assumes individuals mate randomly; unbiased PID which corrects for sampling a small number of individuals and, sibs PID which assumes the population is composed of siblings, a possible scenario in L. franklinii due to inbreeding in some stands (Shapcott 1997).

\section{Results and Discussion}

In total, 10 loci could be reliably scored and displayed polymorphism (Table 2). The ten loci had between two and thirteen alleles in all 84 samples, with five loci having more than four alleles. The average number of alleles ranged from 3.0 to 4.7 per population, and the average observed heterozygosity and expected heterozygosity across the three populations was 0.39 (0.34-0.42) and 0.51 (0.37-0.44), respectively (Table 3). No significant deviations from Hardy-Weinberg equilibrium expectations were detected for any loci except for Huon_24367 in the Corinna population ( $P=0.0044)$. Additionally, allele frequencies appeared independent among loci except for Huon_23863 with Huon_50967 and Huon_2030 in the Corinna population $(\mathrm{P}<0.0001)$.
Multi-locus probability of identity values were below the threshold value (0.01) considered by Waits et al. (2001) to reliably distinguish between individual genotypes even under the sibs PID (Table 4). This indicates that our markers will be effective for identifying both sexually derived individuals in populations where inbreeding is prevalent and individuals derived from clonal reproduction.

None of the M. colensoi samples produced amplified products that could be reliably scored using the 10 loci, despite multiple attempts. Additionally, testing the DNA using universal primers (Internal Transcribed Spacer (ITS)) produced clear PCR products indicating that DNA quality was not causing the failures. The failure of markers to transfer is probably due to the deep evolutionary divergence between $M$. colensoi and $L$. franklinii estimated to have occurred approximately 64 mya (Biffin 2011).

We have developed ten polymorphic microsatellite markers, the first reported, for $L$. franklinii. The markers will be useful for examining both range-wide level processes shaping the species genetic diversity and population level processes including the role of asexual reproduction in the regeneration of $L$. franklinii.

Table 2

Characteristics of the 10 microsatellite markers developed for Lagarostrobos franklinii.

\begin{tabular}{|c|c|c|c|c|c|c|c|}
\hline \multicolumn{2}{|l|}{ Locus } & \multirow{2}{*}{$\begin{array}{l}\text { Forward Primer }\left(5^{\prime}-3^{\prime}\right) \\
\text { GCGAGGTTCAAGGTGATGAT }\end{array}$} & \multirow{2}{*}{$\begin{array}{l}\text { Repeat Motif } \\
\text { (TA)8 }\end{array}$} & \multirow{2}{*}{$\begin{array}{l}\text { Allele Size Range } \\
\text { (bp) } \\
217-253\end{array}$} & BLASTX Top Hit Description & \multirow{2}{*}{$\begin{array}{l}\text { Genbank Acces- } \\
\text { sion } \\
\text { MK423885 }\end{array}$} & Evalue \\
\hline Huon_23318 & $\mathrm{F}:$ & & & & - & & - \\
\hline & $\mathrm{R}:$ & TGAGGACTTTCGGTTGCTCT & & & & & \\
\hline \multirow[t]{2}{*}{ Huon_50967 } & $\mathrm{F}:$ & AATTCGCTTTGAGCCAAGAA & (TC) 18 & 164-196 & - & MK423890 & - \\
\hline & $\mathrm{R}:$ & AGAGGCTTGCCTTGTCAAAA & & & & & \\
\hline \multirow{2}{*}{ Huon_2030 } & $\mathrm{F}:$ & ATGTGCTTGTGAACCCCTGT & $(A G) 9$ & $394-408$ & unknown [Picea sitchensis] & MK423881 & 0 \\
\hline & $\mathrm{R}:$ & TTGAGGCAATCCTTTGGAAC & & & ABR17991.1 & & \\
\hline \multirow[t]{2}{*}{ Huon_23863 } & $\mathrm{F}:$ & CCAGTTCAGTCAGAAGCCG & (AT) 10 & 273-295 & - & MK423886 & - \\
\hline & $\mathrm{R}:$ & TTCCATTCCAGCATTGTTGA & & & & & \\
\hline \multirow[t]{2}{*}{ Huon_18442 } & $\mathrm{F}:$ & TAACTATGGGCTCCTCCACG & (CT) 9 & $144-170$ & unknown [Picea sitchensis] & MK423884 & 3.00E-07 \\
\hline & $\mathrm{R}:$ & AACCATGCAAAGAGGAATGG & & & ABR16594.1 & & \\
\hline \multirow[t]{2}{*}{ Huon_44177 } & $\mathrm{F}:$ & GGACCACATATTTGCAGAAACA & $(\mathrm{AC}) 6(\mathrm{AT}) 6$ & $255-257$ & - & MK423889 & - \\
\hline & $\mathrm{R}:$ & GAAGAATTGGAAATATGGCACA & & & & & \\
\hline \multirow[t]{2}{*}{ Huon_3945 } & F: & GGTTTGCAGGATCTATCAAAAA & $(\mathrm{AT}) 9$ & $303-341$ & unknown [Picea sitchensis] & MK423882 & $1.00 \mathrm{E}-04$ \\
\hline & R: & AGAAGCTTCGGTGAGAACCA & & & ABK23978.1 & & \\
\hline Huon_13112 & F: & TCCTGTTTAGCTCCAAATGCT & (AT) 12 & $255-265$ & - & MK423883 & - \\
\hline \multirow[t]{2}{*}{ Huon_24367 } & $\mathrm{F}:$ & GGAAGTGCATGGGAAGGTAA & (AT) 13 & 291-297 & - & MK423887 & - \\
\hline & $\mathrm{R}:$ & ATGGCCCTAACACTCTGGTG & & & & & \\
\hline Huon_29065 & $\begin{array}{l}\mathrm{F}: \\
\mathrm{R}:\end{array}$ & $\begin{array}{l}\text { AAACTAGGACACCCATCCCC } \\
\text { GATTCCCCCTCTCTCACACA }\end{array}$ & $(\mathrm{TA}) 8$ & $127-135$ & - & MK423888 & - \\
\hline
\end{tabular}


Table 3

Genetic diversity of the 10 polymorphic nuclear microsatellites assessed across three populations of Lagarostrobos franklinii.

\begin{tabular}{|c|c|c|c|c|c|c|c|c|c|c|c|c|}
\hline \multirow[b]{2}{*}{ Locus } & \multicolumn{3}{|c|}{ Corrina $(n=27)$} & \multicolumn{3}{|c|}{ Denison Rv $(n=30)$} & \multicolumn{3}{|c|}{ Lake Judd ( $n=27)$} & \multicolumn{3}{|c|}{ All Samples $(n=84)$} \\
\hline & A & Ho & $\mathrm{He}$ & $A$ & Ho & $\mathrm{He}$ & $A$ & Ho & $\mathrm{He}$ & A & Ho & $\mathrm{He}$ \\
\hline Huon_23318 & 5 & 0.30 & 0.29 & 8 & 0.37 & 0.40 & 4 & 0.56 & 0.74 & 13 & 0.40 & 0.58 \\
\hline Huon_50967 & 4 & 0.37 & 0.37 & 5 & 0.57 & 0.61 & 2 & 0.04 & 0.04 & 7 & 0.33 & 0.40 \\
\hline Huon_2030 & 3 & 0.56 & 0.59 & 3 & 0.63 & 0.62 & 3 & 0.15 & 0.14 & 3 & 0.45 & 0.60 \\
\hline Huon_18442 & 6 & 0.78 & 0.77 & 6 & 0.33 & 0.30 & 3 & 0.33 & 0.47 & 8 & 0.48 & 0.61 \\
\hline Huon_44177 & 1 & 0.00 & 0.00 & 2 & 0.07 & 0.06 & 1 & 0.00 & 0.00 & 2 & 0.02 & 0.02 \\
\hline Huon_3945 & 3 & 0.59 & 0.52 & 8 & 0.70 & 0.62 & 4 & 0.74 & 0.60 & 8 & 0.68 & 0.62 \\
\hline Huon_13112 & 5 & 0.78 & 0.73 & 5 & 0.60 & 0.66 & 4 & 0.62 & 0.64 & 6 & 0.65 & 0.76 \\
\hline Average & 3.40 & 0.42 & 0.44 & 4.70 & 0.42 & 0.43 & 3.00 & 0.34 & 0.37 & 5.90 & 0.39 & 0.51 \\
\hline
\end{tabular}

Note: $\mathrm{A}$ = number of alleles; $\mathrm{He}=$ expected heterozygosity; $\mathrm{Ho}=$ observed heterozygosity; $\mathrm{n}$ = number of individuals sampled. Locality and voucher

information is provided in Appendix 1.

Table 4

The probability of identity (PID) values for each of the 10 polymorphic loci.

\begin{tabular}{|c|c|c|c|c|c|c|}
\hline & & PID by loce & & & Cumulative PI & \\
\hline Locus & biased & unbiased & sibs & biased & unbiased & sibs \\
\hline Huon_23318 & 0.201 & 0.189 & 0.512 & 0.2009 & 0.1887 & 0.5122 \\
\hline Huon_50967 & 0.377 & 0.364 & 0.645 & 0.07572 & 0.06866 & 0.3305 \\
\hline Huon_2030 & 0.225 & 0.218 & 0.504 & 0.01703 & 0.01495 & 0.1666 \\
\hline Huon_23863 & 0.382 & 0.374 & 0.624 & 0.0065 & 0.005588 & 0.104 \\
\hline Huon_18442 & 0.178 & 0.167 & 0.488 & 0.001156 & 0.0009329 & 0.05074 \\
\hline Huon_44177 & 0.954 & 0.952 & 0.977 & 0.001103 & 0.0008885 & 0.04955 \\
\hline Huon_3945 & 0.214 & 0.208 & 0.491 & 0.0002362 & 0.0001846 & 0.02434 \\
\hline Huon_13112 & 0.095 & 0.089 & 0.395 & 0.00002254 & 0.00001643 & 0.009619 \\
\hline Huon_24367 & 0.217 & 0.212 & 0.491 & 0.000004899 & 0.000003475 & 0.004723 \\
\hline Huon_29065 & 0.424 & 0.416 & 0.657 & 0.000002078 & 0.000001445 & 0.003103 \\
\hline
\end{tabular}

\section{Acknowledgements}

The authors thank Miguel de Salas, Jarrah Vercoe, Klaus Meiners and Pierre Feutry for assistance with sample collection and Sean Graham and Eric Carpenter for providing data from the Plant OneKP Project repository. We thank the Department of Primary Industries, Parks, Water and Environment, Tasmanian Government, for providing collection permits (TFL6005 and TFL17332) and Sustainable Timber Tasmania for a collection permit (no. 1461). This work was funded by a Forestry and Forest Products Research Institute, Tsukuba, Japan grant (no. 201430). We thank the Ngāi Tahu Research Consultation Committee for their support (no. 20190212), Tom Myers and Kate Caldwell at the Dunedin Botanical Gardens, and Andy Nilsen for running the ITS PCR.

\section{References}

Anker SA, EA Colhoun, CE Barton, M Peterson, Barbetti M (2017) Holocene Vegetation and Paleoclimatic and Paleomagnetic History from Lake Johnston, Tasmania. Quaternary Research 56(2):264-274. https://dx.doi.org/10.1006/qres.2001.2233

Biffin E, JG Conran, Lowe AJ (2011) Podocarp Evolution: A Molecular Phylogenetic Perspective. Smithsonian Contributions to Botany 95:1-20. https://dx.doi.org/https://doi.org/10.5479/si.0081024X.95.1

Brownstein MJ, JD Carpten, Smith JR (1996) Modulation of non-templated nucleotide addition by taq DNA polymerase: Primer modifications that facilitate genotyping. Biotechniques 20(6):1004. https://dx.doi.org/10.2144/96206st01

Buckley BM (1997) Climate Variability in Tasmania Based on Dendroclimatic Studies of Lagarostrobos franklinii. PhD. Institute of Antarctic and Southern Ocean Studies University of Tasmania, $186 \mathrm{p}$ 
Clark CM, Carbone I (2008) Chloroplast DNA phylogeography in long-lived Huon pine, a Tasmanian rain forest conifer. Canadian Journal of Forest Research-Revue Canadienne De Recherche Forestiere 38(6):1576-1589. https://dx.doi.org/10.1139/X07-209

DPIPWE (2011) Huon Pine [online]. Available from $<$ https://www.parks.tas.gov.au/file.aspx?id=6575>

Gibson N (1988) A description of the Huon Pine (Lagarostrobos franklinii (Hook. f.) C.J. Quinn) forests of the Prince of Wales and King Billy Ranges. Papers and Proceedings of the Royal Society of Tasmania 122(2):127-133 https://doi.org/10.26749/rstpp.122.2.127

Gibson N, Davies J, Brown MJ (1991) The Ecology of Lagarostrobos franklinii (Hook F) Quinn (Podocarpaceae) in Tasmania .1. Distribution, Floristics and Environmental Correlates. Australian Journal of Ecology 16(2):215-222. https://dx.doi.org/DOI 10.1111/j.1442-9993.1991.tb01048.x

Jordan GJ, Harrison PA, Worth JRP, Williamson GJ, Kirkpatrick JB (2016) Palaeoendemic plants provide evidence for persistence of open, well-watered vegetation since the Cretaceous. Global Ecology and Biogeography 25(2):127140. https://dx.doi.org/10.1111/geb.12389

Kerr GJ, McDermott H (1999) The Huon pine story : the history of harvest and use of a unique timber. Portland, Victoria: Mainsail Books, $300 \mathrm{p}$

Molloy BPJ (1995) Manoao (Podocarpaceae), a New Monotypic Conifer Genus Endemic to New-Zealand. New Zealand Journal of Botany 33(2):183-201. https://dx.doi.org/10.1080/0028825x.1995.10410483

Peakall R, Smouse PE (2006) GENALEX 6: genetic analysis in Excel. Population genetic software for teaching and research. Molecular Ecology Notes 6(1):288-295. https://dx.doi.org/10.1111/j.1471-8286.2005.01155.x

Pedley J, Brown MJ, Jarman SJ (1980) A survey of Huon pine in the Pieman River State Reserve and environs. Hobart, Tasmania

Peterson MJ (1990) Distribution and conservation of Huon pine. Forestry Commission Tasmania

Raymond M, Rousset F (1995) GENEPOP (v1.2): Population genetics software for exact tests and ecumenicism. Jorunal of Heredity 86:248-249. https://dx.doi.org/https://doi.org/10.1093/oxfordjournals.jhered.a111573

Read J, Busby JR (1990) Comparative Responses to Temperature of the Major Canopy Species of Tasmanian Cool Temperate Rain-Forest and Their Ecological Significance .II. Net Photosynthesis and Climate Analysis. Australian Journal of Botany 38(2). https://dx.doi.org/10.1071/bt9900185

Reid JB, Hill RS, Brown MJ, HM J (1999) Vegetation of Tasmania. CSIRO Publishing, $476 \mathrm{p}$

Shapcott A (1997) Population genetics of the long-lived huon pine Lagarostrobos franklinii: An endemic Tasmanian temperate rainforest tree. Biological Conservation 80(2):169-179. https://dx.doi.org/Doi 10.1016/S0006-3207(96)00076-6

Styger J, Marsden-Smedley J, Kirkpatrick J (2018) Changes in Lightning Fire Incidence in the Tasmanian Wilderness World Heritage Area, 1980-2016. Fire 1(3). https://dx.doi.org/10.3390/fire1030038

Valiere N (2002) GIMLET: a computer program for analysing genetic individual identification data. Molecular Ecology Notes 2(3):377-379. https://dx.doi.org/10.1046/j.1471-8286.2002.00228.x

Waits LP, Luikart G, Taberlet P (2001) Estimating the probability of identity among genotypes in natural populations cautions and guidelines. Molecular Ecology 10(249-256):249-256. https://dx.doi.org/DOI 10.1046/j.1365-294X.2001.01185.x

Worth JRP, Jordan GJ, Marthick JR, Sakaguchi S, Colhoun EA, Williamson GJ, Ito M, Bowman DMJS (2017) Fire is a major driver of patterns of genetic diversity in two co-occurring Tasmanian palaeoendemic conifers. Journal of Biogeography 44(6):1254-1267. https://dx.doi.org/10.1111/jbi.12919 